\title{
Hydro-Economic based Model of Damage and Loss Analysis of Winongo River Flood
}

\author{
Muhammad Rifki Hardika \\ Tamaris Hydro Company, South Jakarta, INDONESIA \\ muhammadrifq@gmail.com
}

\begin{abstract}
Winongo River experienced considerably high flow that caused overflows along the downstream part of the river and some inundation at the surrounding area. The inundation has reached up to $1 \mathrm{~m}$ spread over the Tegalrejo Sub-district of Yogyakarta City and swept two houses. This paper analyses the damage and loss due to the flood by taking into account the hydraulics phenomena and the economic impact at the inundation area. A hydraulics model has been developed to study the flow characteristics during the flood of Winongo River, especially in the river reach in Tegalrejo Sub-district. The hazard-induced damages in the flooded area were identified and the economic impacts were studied. Several related software have been utilized to analyse the damage and loss of the disaster, including the HEC-RAS 5.0, ArcGIS, HEC-GeoRAS and InaSAFE. Through the integration of the characteristics of both flood phenomena and the economic factor, the damage and loss were then analysed and the Average Annual Damage (AAD) of approximately IDR 88,750,000,000 was obtained.
\end{abstract}

Keywords: Damage and loss, economic impact of flood, hydraulics simulation, flood and inundation

\section{INTRODUCTION}

On March $12^{\text {th }} 2016$, a big flood event happened along the Winongo River which was located in Yogyakarta. The Winongo River is located in the border area of Sleman, Bantul, and Yogyakarta City. Based on the statistical data, the population of Tegalrejo Subdistrict is approximately 36,621 people (BPS Yogyakarta City, 2016). Winongo River is supplied by two big rivers from the upstream. The most severely affected area is Tegalrejo Sub-district. The flood occurred in the night so that some residents did not have time to evacuate their goods. Over 500 houses and 1,600 persons were affected by flood inundation. The previous big flood occurred in 2015 with similar damage.

Since the floods can threat the safety of human life and cause property losses, the objectives of this research are as follows.

a) Demonstrate the application of the integrated hydrodynamic and loss assessment model in Winongo River using HEC-RAS 5.0 version.

b) Determine the flood consequences, related to the estimation of direct damage and the number of potential fatalities using InaSAFE Software.

c) Create a geographical map related to information in damage analysis modeling.

d) Develop the loss-frequency and annual loss function.
The model enables to demonstrate a case study in estimating average flood damage in the largest floodprone area of the Winongo River. The map of damage can be used to obtain the loss-frequency function for estimating losses.

\section{HYDRAULICS SIMULATION}

\subsection{Hydraulics simulation software of HEC-RAS 5.0 Version}

HEC-RAS is one-dimensional channel or river hydraulics model used for steady flow and unsteadyflow water surface profile computations through a network of open channels (U.S. Army, 1989). The HEC-RAS v. 5.0 has two-dimensional hydraulic analysis in the form RAS Mapper. Generally, HECRAS consists of four components, there are steady flow water surface profile computations, one and twodimensional simulation unsteady flow, movable boundary sediment transport computations, and water quality analysis.

In this research, the boundary condition used the one and two-dimensional unsteady flow simulation. The unsteady flow component can be used to perform subcritical, supercritical, and mixed flow regime (subcritical, supercritical, hydraulic jumps, and drawdowns) calculations in the unsteady flow computations module. The hydraulic calculations for bridges, culverts, and other hydraulic structures 
developed for the steady flow component were incorporated into the unsteady flow module. The newest feature in HEC-RAS v.5.0 is the capability to perform inundation mapping of water surface profile result directly. The inundation depth and floodplain boundary data sets are created through the RAS Mapper by using HEC-RAS geometry and the computed water surface profiles.

The basic data needed to calculate hydraulic profiles of a channel are the discharge, channel geometry, water elevation at a control section and channel roughness. Flow discharge was a given data and the channel geometry was obtained from field measurements. Usually, the water elevation at control section (boundary condition) and channel roughness are unknown and have to be estimated by indirect ways. With this option, the program calculates the critical depth for the section and uses it as boundary condition. This option applies to a case where there is a control structure such as weir, gate or drop that controls and forces the critical depth. The water level is interpolated from the given rating curve. Usually, this case applies for control section in which there are sufficient data of measured water levels and discharges are measured constantly.

\subsection{HEC-GeoRAS as secondary software}

HEC-GeoRAS is a set of procedures, tools, and utilities for processing geospatial data in ArcGIS using a graphical user interface (GUI). The interface allows the preparation of geometric data for importing into HEC-RAS and processes simulation results exported from HEC-RAS. It needs an existing digital terrain model (DTM) of the river system in the ArcInfo TIN format to create the river cross-section. The user creates a series of line themes pertinent to developing geometric data for HEC-RAS. The themes created are the Stream Centreline, Flow Path Centrelines (optional), Main Channel Banks (optional), and Cross Section Cut Lines referred to as the RAS Themes.

\subsection{Previous Studies}

Pawestri, et al. (2016) reviewed the inundation area caused by overflowed Bogowonto River during the rainy season. The research mainly aims to develop flood hazard map and study the characteristics of flood in the study area. There are two main analyses, namely hydrologic and hydraulic, to model a flood event. Hydrologic and hydraulic modeling of flood based on 20 and 50 years return period hydrograph along the river geometry is done using the latest HEC program namely HEC-HMS 4.1 and HEC-RAS 5.0. In addition, ArcGIS 10.3 is used as a terrain pre- processor and post-processor for hazard mapping. The results of this research are flood hazard maps for 20 and 50 years flood and its comparison to the recent major flood events. Flood inundation model covered an area of $993.77 \mathrm{Ha}$ and 1,175.86 Ha, with maximum discharge calculated at Boro Weir as starting point were $1,206.2 \mathrm{~m}^{3} / \mathrm{s}$ and $1,397.3 \mathrm{~m}^{3} / \mathrm{s}$ for 20 and 50 years flood case respectively.

Maharani (2016) conducted a study to develop Winongo River flood risk map in Tegalrejo, Gedongtengen, Wirobrajan, Jetis, Mantrijeron, and Ngampilan Sub-district study which used 25 years return period for the flood hydrograph and applied hydraulic and hydrology analysis used HEC-RAS 4.1 and HEC-HMS respectively. Waluyadi (2007) studied the performance of flood management planning with hydro-economy approach that considers hydrology aspect, hydraulic aspect, and economic aspect in Ciliwung River, DKI Jakarta. The study on hydroeconomic approach was also conducted by Mas (2015) for flood management plan in Gunung Sari Channel using HEC-FDA Software which can develop risk analysis by including economic consideration.

\section{HYDROLOGY ANALYSIS}

\subsection{Nakayasu Synthetic Unit Hydrograph}

Nakayasu synthetic unit hydrograph (SUH) is used in developing flood hazard map and designing the hydraulic structure. Nakayasu SUH is presented in the following equation.

$$
\begin{aligned}
& Q_{P}=\frac{1}{3,6}\left(\frac{A R_{e}}{0,3 T_{p}+T_{0,3}}\right) \\
& T_{P}=t_{g}+0,8 t_{r}
\end{aligned}
$$

$t_{g}=0,4+0,058 L$

For $L>15 \mathrm{~km}$

$t_{g}=0,21 L^{0,7}$

$$
\text { For } L \leq 15 \mathrm{~km}
$$

$T_{0,3}=\alpha t_{g}$

$t_{r}=0,5 t_{g}-t_{g}$

where $Q_{P}$ is peak discharge $\left(\mathrm{m}^{3} / \mathrm{s}\right), \underline{A}$ is the area of watershed $\left(\mathrm{km}^{2}\right), R_{e}$ is effective rainfall $(1 \mathrm{~mm}), T_{p}$ is time to peak (hours), $\mathrm{T}_{0.3}$ is time from peak discharge until 0.3 peak discharge (hours), $t_{g}$ is time of 
concentration (hours), $T_{r}$ is rainfall time unit (hours), $\alpha$ is characteristic coefficient, and $L$ is length of main river $(\mathrm{km})$.

\subsection{Hydraulic Analysis}

HEC-RAS is used in hydraulic analysis to make flood modeling. The basic equations which are commonly used are as follows:

$Q=A V$

$V=\frac{1}{n} R^{2 / 3} \sqrt{S}$

where $Q$ is discharged $\left(\mathrm{m}^{3} / \mathrm{s}\right), V$ is velocity $(\mathrm{m} / \mathrm{s}), n$ is manning coefficient, $R$ is hydraulic radius, and $S$ is slope of the line energy.

While unsteady flow is used on the open channel (river).

Continuity equation:

$$
\frac{\partial A}{\partial t}+\frac{\partial Q}{\partial x}-q I=0
$$

Momentum equation:

$$
\frac{\partial Q}{\partial t}+\frac{\partial Q V}{\partial x}+g A\left(\frac{\partial z}{\partial x}+S f\right)=0
$$

where $Q$ is the flow rate $\left(\mathrm{m}^{3} / \mathrm{s}\right), A$ is the look of the river $\left(\mathrm{m}^{2}\right), q_{l}$ is a discharge inflow lateral direction $\left(\mathrm{m} / \mathrm{s}^{2}\right), X$ is the distance elongated the river $(\mathrm{m}), t$ show time (s), gis the acceleration gravity $\left(\mathrm{m} / \mathrm{s}^{2}\right), V i s$ the flow velocity $(\mathrm{m} / \mathrm{s}), \frac{\partial z}{\partial x}$ is the slope of water surface, and $S_{f}$ is the slope of the line energy defined as follows:

$$
S_{f}=\frac{n^{2} Q \mid Q}{A^{2} R^{2 / 3}}
$$

where $n$ is Manning coefficient and $R$ is hydraulics radius.

The equation used to analyze hydrodynamic in this application is the basic equation of energy. Water level profiles are calculated by the energy equation with the standard iteration procedure. The energy equation is as follows:

$$
y_{2}+z_{2}+\frac{\alpha_{2} v_{2}}{2 g}=y_{1}+z_{1}+\frac{\alpha_{1} v_{1}}{2 g}+h_{e}
$$

where $y_{1}$ and $y_{2}$ is water depth $(\mathrm{m}), z_{1}$ andz $\mathrm{z}_{2}$ is distance from reference line $(\mathrm{m}), \alpha_{1}$ and $\alpha_{2}$ coefficient of velocity, $v_{l}$ and $v_{2}$ is flow velocity $(\mathrm{m} / \mathrm{s}), g$ is acceleration of gravity $\left(\mathrm{m} / \mathrm{s}^{2}\right)$, and $h_{e}$ is head loss $(\mathrm{m})$.

Loss of energy is calculated based on the roughness and contraction of water flow. The energy loss equation is as follows:

$$
h_{e}=L \bar{S}_{f}+C\left|\frac{\alpha_{2} V_{2}^{2}}{2 g}-\frac{\alpha_{1} V_{1}^{2}}{2 g}\right|
$$

where $L$ is length of the two cross section on the river, $S_{f}$ is manning value between two cross section on the river, and $C$ is coefficient of loss due to contraction.

\section{DIRECT PHYSICAL DAMAGE}

The direct physical damages can be calculated by averages of a maximum damage amount per damaged object (such as a building, a square meter of land, or a meter of road). This value is assumed the same countrywide for the same type of object. Currently, site-specific conditions or regional differentiation are not accounted for in the assessment procedure (Jonkman, et al., 2007). Illustration in estimating the fraction of maximum damage as a function of selected flood characteristics like water depth and flow velocity is shown in Figure 1.

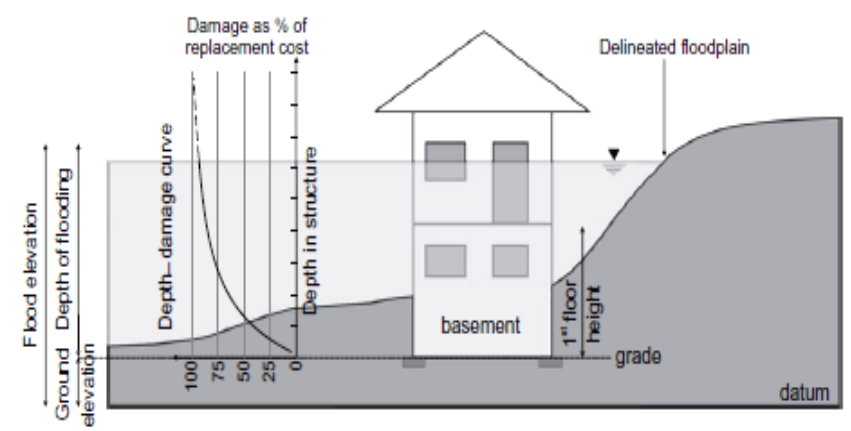

Figure 1. Depth-damage functions of relevant flood depth.

The following equation describing how the parameters in the direct damage model are combined to estimated total of physical damages on the floodplain.

$D=\sum_{i}^{m} \sum_{r}^{n} \alpha_{i}\left(h_{r}\right) D_{\max , i} n_{i, r}$

where $D_{\max , i}$ is maximum damage amount for an object or land use category $i, i$ is damage or land use category, $r$ is location in floodplain, $m$ is number of damage categories, $n$ is number of locations in flooded 
area, $h_{r}$ is hydraulic characteristics of the flood at a particular location, $\alpha_{i}\left(h_{r}\right)$ is stage-damage function that express the fraction of maximum damage for category $i$ as a function of flood characteristics at particular location $\mathrm{r}\left(0 \leq \alpha_{\mathrm{i}},\left(\mathrm{h}_{\mathrm{r}} \leq 1\right), n_{i, r}\right.$ is the number of objects of damage category $i$ at location $r$.

Based on the "Pedoman Umum Pengkajian Risiko Bencana" (BNPB, 2012) the parameter of risk parameter index as shown in Table 1 was overlaid to the flood risk with Digital Elevation Model for the flood inundation.

Table 1. Risk parameter index

\begin{tabular}{lllll}
\hline Depth $(\mathrm{m})$ & Class & Value & Weight $(\%)$ & Score \\
\hline$<0.76$ & Low & 1 & & 0.333 \\
$0.76-1.5$ & Mid & 2 & 100 & 0.666 \\
$>1.5$ & High & 3 & & 1 \\
\hline
\end{tabular}

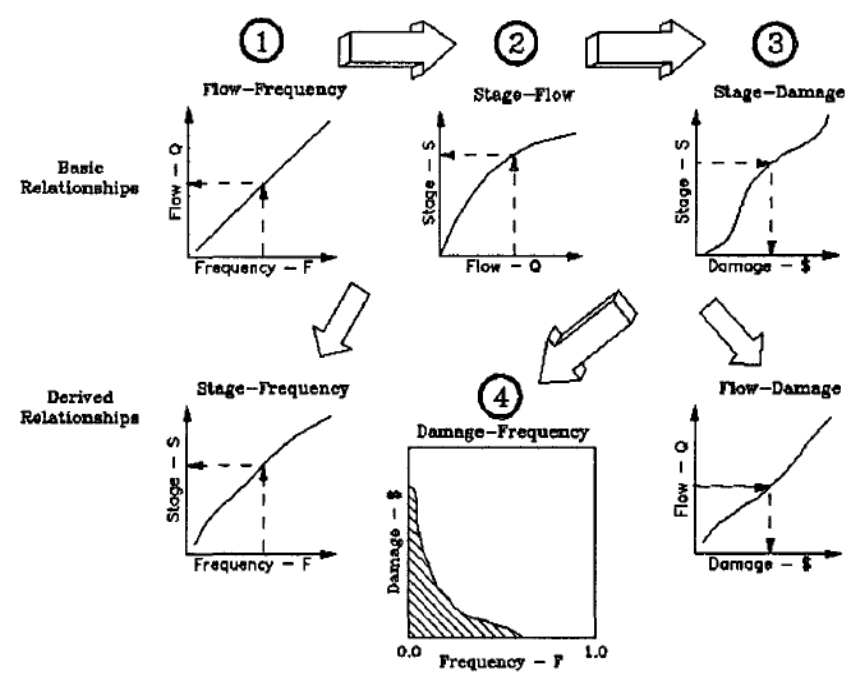

Figure 2. AAD calculation scheme (U.S. Army, 1989)

The conceptual thinking to assess the flood loss management is to know Average Annual Damage (AAD). AAD describes the price of a residential property as the sum of principal, interest, taxes, utility, insurance, and flooding. Integrated analysis of hydrology, hydraulic and economic aspects are used to manage damage susceptibility (U.S. Army, 1989). The basic matrices that can represent the hydrologic, hydraulic, and economic characteristics of flood plain management measures are the stage-damage relationship, stage-flow or rating curve, and the flowfrequency relationship or flood frequency. All others function such as flow-damage, stage-frequency and damage-frequency can be obtained from these basic three by combinations with the common parameter. All the function and how to integrate each other are shown in Figure 2.

\section{RESEARCH METHODOLOGY}

\subsection{Description of research location}

Winongo River is located in the Tegalrejo Subdistrict, Yogyakarta Province. The length of the river is $\pm 29 \mathrm{~km}$. The watershed of Winongo River located in Opak sub-catchment which has approximately 137 $\mathrm{km}^{2}$ area. The detailed location of upstream and downstream boundary of this research is presented in Table 2. The river length studied in this research was $3.5 \mathrm{~km}$

Table 2. Coordinate of the river boundary

\begin{tabular}{lll}
\hline \multirow{2}{*}{ Boundary } & \multicolumn{2}{l}{ Coordinate (UTM) } \\
\cline { 2 - 3 } & $\mathrm{x}$ & $\mathrm{y}$ \\
\hline Upstream & 428571.08 & 9141455.34 \\
Downstream & 428893.56 & 9139396.00 \\
\hline
\end{tabular}

\subsection{Simulation Scenario}

The hydraulic simulation was conducted using HECRAS 5.0 version. There were 4 scenarios to run this simulation model for flood hazard mapping. The first scenario applied flow discharge for 5 year flood return period to test the capability of the inline structure. Then, the next scenario applied 10 and 25 years flood. The last scenario used combination of onedimensional and two-dimensional model for 25 years flood discharge with no inline structure estimated to be collapsed. Further detail was listed in Table 3.

Table 3. Simulation scenarios

\begin{tabular}{|c|c|c|c|c|c|}
\hline No & Parameters & Scenario 1 & Scenario 2 & Scenario 3 & Scenario 4 \\
\hline 1 & Unsteady flow modelling & $\sqrt{ }$ & $\sqrt{ }$ & $\sqrt{ }$ & $\sqrt{ }$ \\
\hline 2 & Upstream flow hydrograph & $\mathrm{Q}_{2}$ and $\mathrm{Q}_{5}$ & $\mathrm{Q}_{10}$ & $\mathrm{Q}_{25}$ & Q \\
\hline 3 & Downstream boundary (Rating curve) & $\sqrt{ }$ & $\sqrt{ }$ & $\sqrt{ }$ & $\sqrt{ }$ \\
\hline 4 & Bridge/Culvert & $\sqrt{ }$ & $\sqrt{ }$ & $\sqrt{ }$ & $\sqrt{ }$ \\
\hline 5 & Model Computation & $1 \mathrm{D}$ & $1 \mathrm{D}$ & $1 \mathrm{D}$ & $1 \mathrm{D} / 2 \mathrm{D}$ \\
\hline
\end{tabular}




\subsection{Data collection}

The used data for analyzing the damage and loss in this study were shown in Table 4.

Table 4. Research data collection

\begin{tabular}{lllll}
\hline Data Type & Details & Purpose & Source & Availability \\
\hline Rainfall Data & Daily Rainfall data & Rainfall Design & BBWS SO & $2006-2015$ \\
Base Map & ALOS Digital Elevation Model & Estimation of & BPPTKG & Available \\
& Bing Aerial Map & inundation area & ArcGIS & Available \\
River & Land Cover & Manning Value & Available \\
Geometry & River Contour & Hydraulic & BBWS SO & Available \\
& Inline Structure & Analysis & Field Survey & Available \\
Exposure & Administrative Boundary & Loss Assessment & Open Street & Available \\
& OSM for Buildings Polygon Population Density & Modeling & Map & Available \\
\hline
\end{tabular}

\section{RESULTS AND DISCUSSION}

\subsection{Hydrology analysis}

The study area of Winongo watershed was $31.93 \mathrm{~km}^{2}$, there were four rainfall stations taken into account in this watershed. There are Beran, Angin-angin, Kemput, and Prumpung Station. The rainfall data series was available from 2006 till 2015. The hydrological analysis was carried out to know the design flood discharge on 2, 5, 10, and 25 years return periods.

Thiessen Polygon was generated using ArcGIS Software 10.2.2. From location of four stations in Winongo watershed (see Figure 3). From Thiessen analysis, $\alpha$ value for each station can be determined.

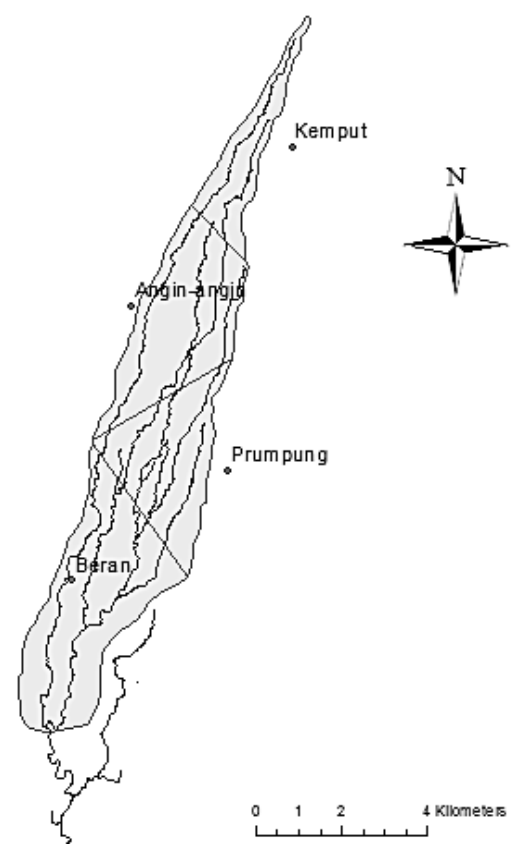

Figure 3. Thiessen polygon.
This research used 4 rainfall stations to estimate the design rainfall. There are Beran, Angin-angin, Kemput, and Prumpung Station. It used 10 years of data series of rainfall from 2006 till 2015. The design rainfall can be calculated by using frequency analysis. The analysis used the statistical data base for the maximum daily rainfall data from 2006 until 2015. Form the frequency analysis, the normal distribution was deemed representing the data which then be used to analyze the return period of design rainfall. The maximum rainfall depth from four stations was shown in Table 5.

Table 5. Maximum daily rainfall data

\begin{tabular}{lll}
\hline No & Year & P $(\mathrm{mm})$ \\
\hline 1 & 2006 & 133.43 \\
2 & 2007 & 54.77 \\
3 & 2008 & 111.31 \\
4 & 2009 & 58.25 \\
5 & 2010 & 149.08 \\
6 & 2011 & 48.98 \\
7 & 2012 & 74.39 \\
8 & 2013 & 36.01 \\
9 & 2014 & 106.09 \\
10 & 2015 & 94.63 \\
\hline & Mean & 86.69 \\
& Max & 149.08 \\
& Min & 36.01 \\
\hline
\end{tabular}

The rainfall duration was determined based on sorting hourly rainfall data from 2009-2015 of all stations. According to the data, duration of rainfall usually occurs within 3 hours duration. There are several approaches to know the rainfall duration, such as Kirpich, Bransby Williams, and Australian Rainfall Runoff that showed in Table 6. 
Table 6. Rainfall duration

\begin{tabular}{ll}
\hline Approach Rainfall Duration & (hour) \\
\hline Kirpich & 3 \\
Bransby Williams & 7 \\
Australian Rainfall Runoff & 3 \\
\hline
\end{tabular}

The appropriate method to calculate rainfall duration in this research was Australian Rainfall Runoff. The control of rainfall duration was analyzed to know flow velocity in the research area. The averaged velocity was $1.78 \mathrm{~m} / \mathrm{s}$.

CN composite value, in this case, does not take into consideration for inundated area. The results of the calculation, the value of $C N$ composite is 77.6813. $C N$ composite value calculation results as described in Table 7.

Table 7.CN composite value calculation (Hardika, 2017)

\begin{tabular}{llll}
\hline Land Use & Area $(\mathrm{km})$ & $C N$ value & $C N_{i} \times A$ \\
\hline Residential & 5.59 & 92 & 514.18 \\
Village & 8.33 & 75 & 625.07 \\
Bush & 0.05 & 65 & 2.97 \\
Fertile Soil & 1.14 & 71 & 80.75 \\
Graveyard & 0.06 & 69 & 4.06 \\
Grassy field & 0.20 & 61 & 12.36 \\
Garden & 0.40 & 72 & 28.71 \\
Padi rice field & 16.17 & 75 & 1212.39 \\
\hline$\sum$ & 31.93 & 580 & 2480.50 \\
\hline Composite CN Value & & 77.6813 \\
\hline
\end{tabular}

The effective rainfall assumed that the wet conditions have the value of $S$ and $I a$ were 31.73 and 6.34, respectively.

\subsubsection{Rainfall Distribution}

Rainfall distribution in this study used maximum rainfall depth for different return period calculated using ABM method. Maximum rainfall depth was shown in Table 8.

Table 8. Maximum rainfall depth

\begin{tabular}{lll}
\hline No & Return Period (year) & $P(\mathrm{~mm})$ \\
\hline 1 & 2 & 86.69 \\
2 & 5 & 118.79 \\
3 & 10 & 135.57 \\
4 & 25 & 153.47 \\
\hline
\end{tabular}

\subsubsection{Unit Hydrograph}

Due to the lack of measured flow discharge data available in the research location, synthetic unit hydrograph (SUH) was used. Nakayasu method was used to know the unit hydrograph on research location. The results Nakayasu SUH can be shown in Figure 4.

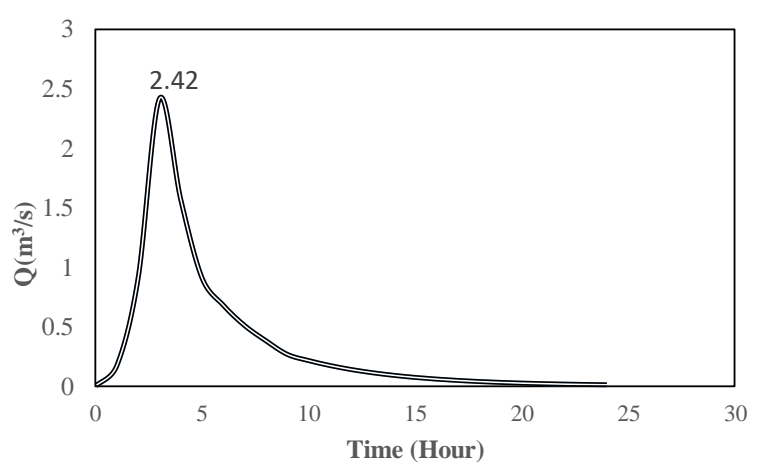

Figure 4. Synthetic unit hydrograph Nakayasu.

The last step to investigate the flood discharge was by multiplying the effective rainfall data with the synthetic unit hydrograph Nakayasu. There are three kinds of design rainfall based on the return periods. The maximum flood discharge for $2,5,10$, and 25 years of return periods were $119.53 \mathrm{~m}^{3} / \mathrm{s}, 160 \mathrm{~m}^{3} / \mathrm{s}$, $187 \mathrm{~m}^{3} / \mathrm{s}$, and $216 \mathrm{~m}^{3} / \mathrm{s}$ respectively. More detailed information was provided in Figure 5 .

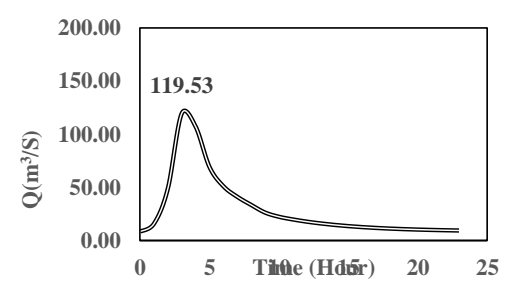

Figure 5. Flood discharge for 2-years return period.

\subsection{Field Survey}

Field survey is very important to set the simulation model based on the real condition. The survey was done on December $7^{\text {th }}$ 2016. There were several survey points along the river station from 1600 till 1400. The inundation elevation was measured by TOPCON rotating laser level RL-H4C series and GPS device. The result of the survey was an average elevation of flood inundation.

\subsection{Hydraulic Analysis}

The hydraulic analysis in this study used HEC-RAS 5.0.0 Version to simulate the scenario model and combination model between one dimensional model for analyzing river channel and two dimensional 
models for analyzing the inundation area caused by flood. The simulation was done along $3.5 \mathrm{~km}$ length.

\subsubsection{River Geometry}

River geometry was generated from the HECGeoRAS analysis. Combination of river cross section and raster data (terrain layer) was used to perform both 1 dimensional and two-dimensional model computations shown in Figure 6 and Figure 7, respectively.

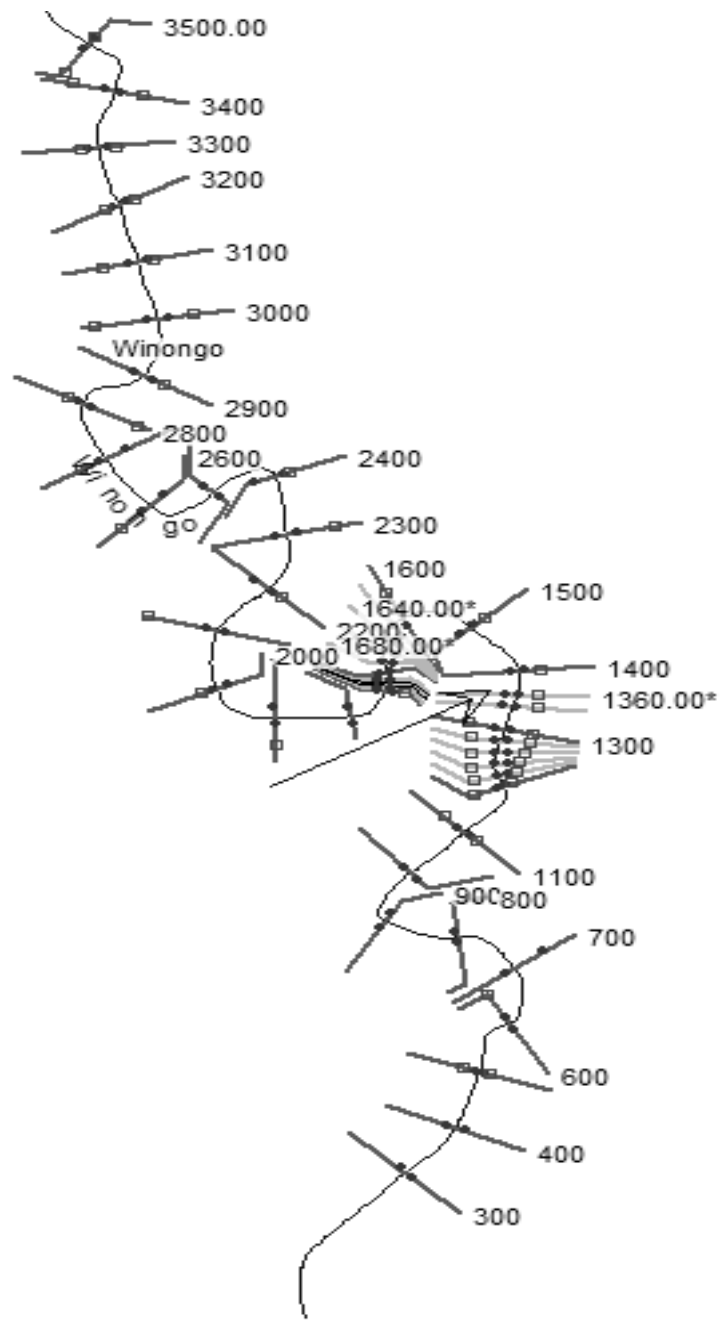

Figure 6. Schematic of river cross section.

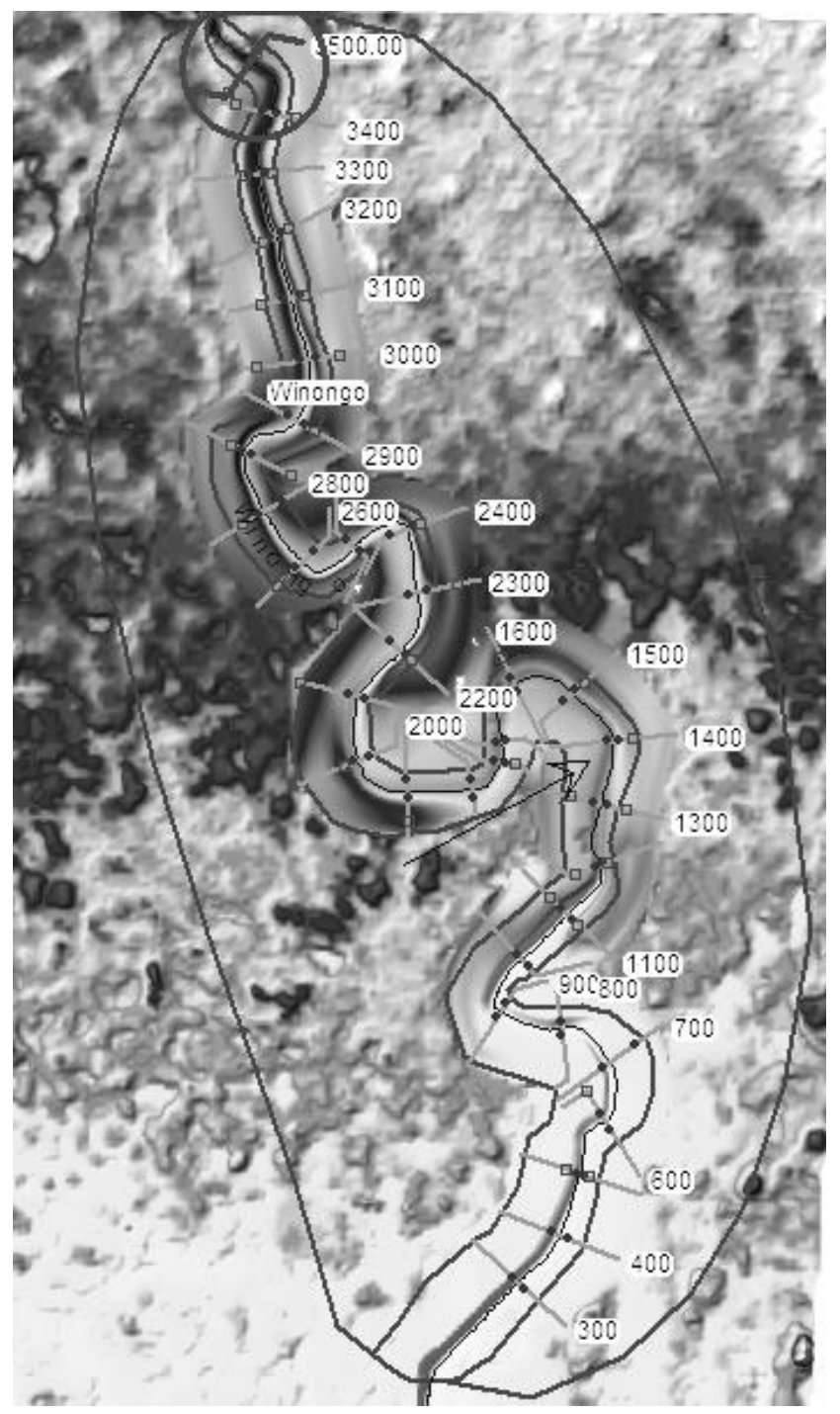

Figure 7. Combination between the raster data and river cross section.

\subsubsection{Boundary Condition}

The boundary condition is used to constraint the upper stream inflow and the downstream outflow. The upstream boundary condition used design flood for 2 , 5,10 , and 25 year return periods. Based on profile plot of the Figure the downstream area was considered as the supercritical flow. Thus, it used the trapezoid approach to developing downstream rating curve. The rating curve was used as presented in Figure 8. 


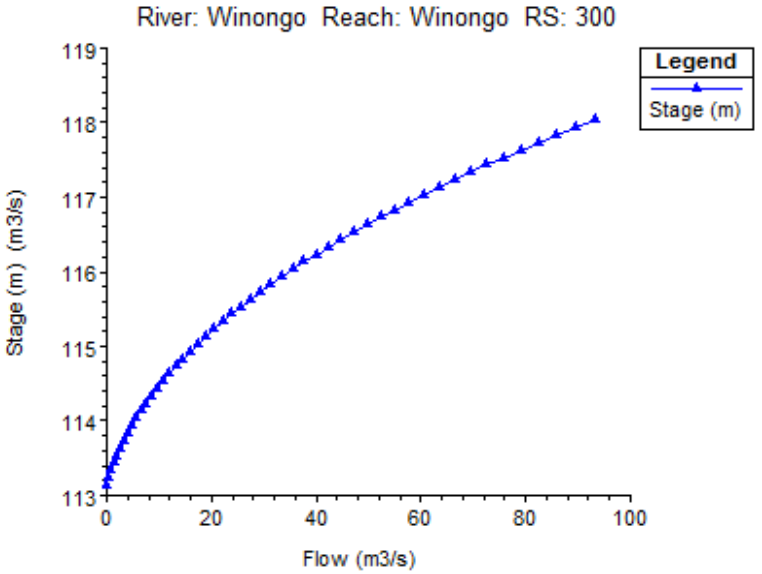

Figure 8. Downstream rating curve.

\subsubsection{Simulation Scenario}

The first scenario used one-dimensional model computation. By using discharge of 5-year return period as upstream boundary condition period discharge as upstream boundary condition. This simulation was to examine the river condition under the existing river geometry condition. The simulation performed smoothly without any numerical instability. Some inundation took place around river station RS1720 and RS1350. There was a strange wall of water surface on the bridge. In some cases, it might be caused by small numerical error. Figure 8 showed the unstable condition in the vicinity of bridges station. The second scenario was then carried out without bridge structures (assuming the bridge was already collapsed) with 10-year return period of flood discharge. Maximum velocity at RS2100 was 3.72 $\mathrm{m} / \mathrm{s}$. Because of the high velocity on the upstream of the bridges, the bridges are set to be collapsed. Recalling the results of Simulation 2, Scenario 3 was then designed by introducing the 25 -yers return period of flood discharge and by assuming the all bridges were already collapsed. The resulted maximum water level elevation from river station RS1800 until RS1300 were shown in Table 9.

Table 9. Maximum water level along Winongo River

\begin{tabular}{lll}
\hline River Station & $\begin{array}{l}\text { Maximum Flood } \\
\text { Elevation }(\mathrm{m})\end{array}$ & River Station \\
\hline 1800 & +129.19 & 1800 \\
1732.426 & +129.19 & 1732.426 \\
1727.79 & +129.07 & 1727.79 \\
1713.9 & +129.01 & 1713.9 \\
1700 & +129.01 & 1700 \\
1600 & +129.01 & 1600 \\
1500 & +128.77 & 1500 \\
1400 & +128.57 & 1400 \\
1360 & +128.41 & 1360 \\
1340 & +127.55 & 1340 \\
1300 & +126.27 & 1300 \\
\hline
\end{tabular}

A combination of one-dimensional (1D) and twodimensional (2D) models were then used to identify the flood inundation area at near downstream Winongo River. The results were then compared with the actual phenomena of the Winongo flooding and the damage and loss were studied accordingly. The output of scenario is used to do loss assessment modelling. The result of the simulation is raster file of the depth and elevation for 2, 5, 10, 25-years return periods. To assess the flood loss analysis, it needs the control cross-section to make the basic function of stage-flow relationship. After doing some field survey, the appropriate control cross-section is on station number 1400 . There are found a stage-flow index aside the bridge on the station 1400 .

The lowest elevation on the river station 1400 is +124.34 m. Thus, flood depth above WGS 1984 UTM zone $49 \mathrm{~S}$ datum can be calculated. Based on the output of fourth scenario, the maximum water surface elevation on river station 1400 for each return period was presented in Table 10.

Table 10. Maximum water level at RS 1400

\begin{tabular}{lll}
\hline Return Period & Elevation $(\mathrm{m})$ & Depth $(\mathrm{m})$ \\
\hline 2 & 127.24 & 2.9 \\
5 & 127.57 & 3.23 \\
10 & 127.82 & 3.48 \\
25 & 127.9 & 3.56 \\
\hline
\end{tabular}

\subsection{Loss Assessment Analysis}

The output of one dimensional and two dimensional was overlaid with the exposure. Open Street Map develops the exposure. According to the recent urban development, the exposure should be updated by editing and adding new buildings with Bing aerial photogrammetry. This section produced the correlation between flood depth and estimated loss for each discharge with certain return periods. Then, it also produced the flood coverage area with certain return periods and the estimated losses. The result in this section was to obtain the loss-frequency function by using several discharges with $2,5,10$, and 25 years return period. Loss assessment was determined by developing the three basic curves. There were flowfrequency relationship, stage-flow relationship, and stage-damage relationship. These three basic function can be developed into loss-frequency which is the final result to get average annual damage on the Winongo flood event. 


\subsubsection{Flood Frequency Function}

This function defines the relationship between exceedance frequency and flows at the research location. The function describes the probability nature of the river flow. This research used 2, 5, 10, and 25years return period flood discharge which is already got from hydrology analysis. The exceedance frequency in percent is associated with the maximum discharge for each year return period. The detailed data was shown in Table 11 and Figure 9.

Table 11. Flood frequency matrix

\begin{tabular}{lll}
\hline Return Period & $\begin{array}{l}\text { Probability of Exceedance } \\
(\%)\end{array}$ & $Q\left(\mathrm{~m}^{3} / \mathrm{s}\right)$ \\
\hline 2 & 50 & 119.53 \\
5 & 20 & 178.77 \\
10 & 10 & 210.34 \\
25 & 4 & 244.28 \\
\hline
\end{tabular}

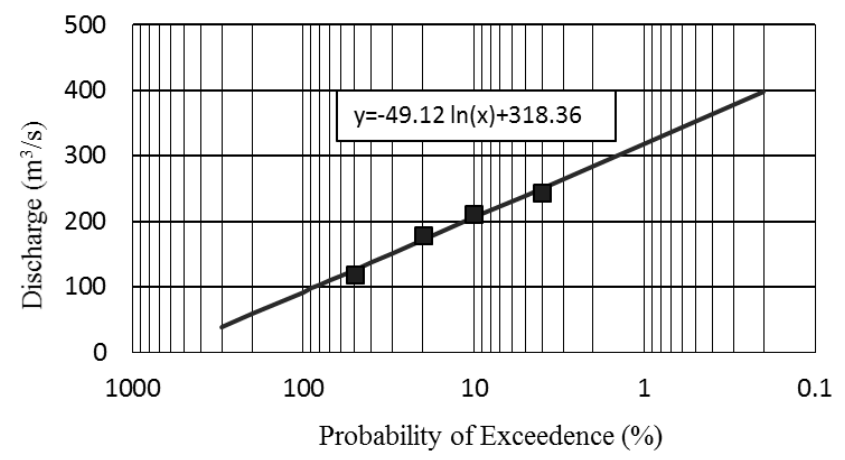

Figure 9. Flood frequency curve.

\subsubsection{Stage-Flow Curve}

Stage-flow defines the relationship between flow rate and stage at the research location. The basic function describes the hydrodynamic on the river based on the HEC-RAS simulation. It is frequently referred into Rating Curve. Relation of hydrology analysis and hydraulic analysis result was then used to develop the Stage-Flow Curve (see Figure 10).

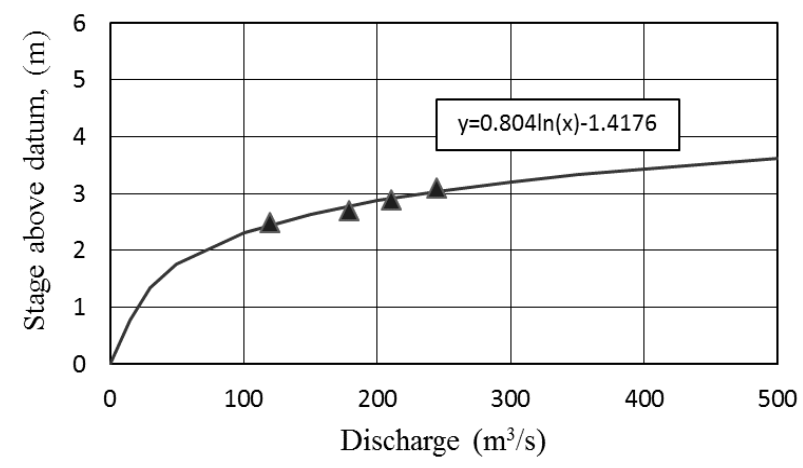

Figure 10. Stage-Flow curve.

\subsubsection{Stage-Loss Curve}

Stage-Loss defines the relationship between water surface elevation and the flood impact which occurs within some distance between upstream and downstream. Based on the field survey, river crosssection in the station 1400 was chosen as the control to evaluate the water surface elevation. The basic function represented level of damage towards the building structure. This research used InaSafe as a tool to know how many structures which are flooded to the specified depth.

According to the "Pedoman Umum Pengkajian Risiko Bencana" (BNPB, 2012) loss index can be obtained from economic, physical component, and environmental. The components depend on type of disaster. This study only considers the physical component to estimate the loss. The flood depth index is shown in Table 12. This loss scenario used $1.5 \mathrm{~m}$ as a threshold. If the buildings are submerged more than 1.5 meters, it was deemed as flooding. Then, 0.76-1.5 $\mathrm{m}$ depth was considered as wet. Buildings were in dry condition if it were submerged between 0.76 and 0.3 meters. BNPB released the guidance to estimate the loss assessment based on the flood index class. The building unit will be multiplied by the prices based on the loss index class. Then, the estimated loss will be weighted based on the building indicator. The flood loss index is shown in the Table 12. The InaSafe input the flood depth based on the 1D/2D HEC-RAS output and building exposure. The input for InaSafe was shown in Table 13.

Table 12. Flood loss index

\begin{tabular}{|c|c|c|c|c|c|c|}
\hline \multirow{2}{*}{$\begin{array}{l}\text { Disas- } \\
\text { ter }\end{array}$} & \multirow{2}{*}{\multicolumn{2}{|c|}{ Indicator }} & \multicolumn{3}{|c|}{ Index Class } & \multirow[b]{2}{*}{ Weight } \\
\hline & & & Low & Low & Low & \\
\hline \multirow{4}{*}{ Flood } & & & & & & \\
\hline & 1 & Residential & $<400$ & $\begin{array}{l}400- \\
800\end{array}$ & $>800$ & $40 \%$ \\
\hline & 2 & $\begin{array}{l}\text { Public } \\
\text { Facilities }\end{array}$ & $<500$ & $\begin{array}{l}500- \\
1000\end{array}$ & $>1000$ & $30 \%$ \\
\hline & 3 & $\begin{array}{l}\text { Critical } \\
\text { Facilities }\end{array}$ & $<500$ & $\begin{array}{l}500- \\
1000\end{array}$ & $>1000$ & $30 \%$ \\
\hline
\end{tabular}

Table 13. Input for InaSafe software

\begin{tabular}{|c|c|c|}
\hline Input Parameter & Name & Source \\
\hline \multirow{2}{*}{ Flood Depth } & Winongo & 1D/2D HEC-RAS \\
\hline & Flood & Analysis ( $4^{\text {th }}$ Scenario) \\
\hline Exposure & Buildings & $\begin{array}{l}\text { Open Street Map } \\
\text { (Edited) }\end{array}$ \\
\hline
\end{tabular}

There are four inputs of flood hazard for 2, 5, 10, and 25 -years return period. First, the simulations do with 
flood coverage area of 25 years return period and building exposures. From the analysis above, the total loss for each return period can be associated with maximum water elevation on river station RS1400. The two parameters were then used to develop the Stage-Loss Curve (see Table 14 and Figure 11).

Table 14. Stage-Loss matrix

\begin{tabular}{llll}
\hline $\begin{array}{l}\text { Return } \\
\text { Period }\end{array}$ & Elevation (m) & Depth (m) & $\begin{array}{l}\text { Loss (billion } \\
\text { IDR) }\end{array}$ \\
\hline 2 & 127.24 & 2.9 & 51.14 \\
5 & 127.57 & 3.23 & 68.88 \\
10 & 127.82 & 3.48 & 75.9 \\
25 & 127.9 & 3.56 & 84.96 \\
\hline
\end{tabular}

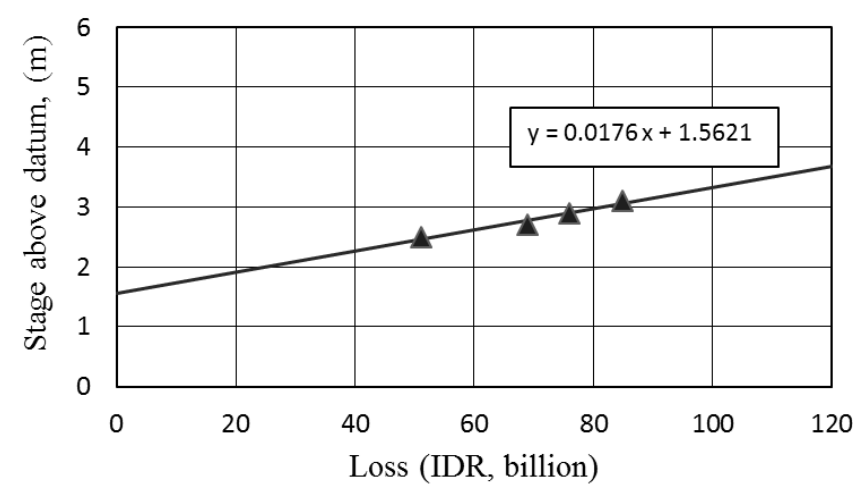

Figure 11. Stage-Loss curve

\subsubsection{Average Annual Damage (AAD)}

The average annual damage (AAD) is the integration of the flood loss density curve over all the probability of exceedance. To get the average annual damage, loss-frequency matrix is necessary. The average annual damage was computed as the integral of that loss-frequency function. The loss-frequency relationship was derived by combining the basic function (Figure 9, 10, and 11) and using the common parameters of stage and flow. The matrix function was shown in Table 15.

Table 15. Development of Loss-Frequency matrix

\begin{tabular}{lllll}
\hline $\begin{array}{l}\text { Return } \\
\text { Period }\end{array}$ & $\begin{array}{l}\text { Probability of } \\
\text { Exceedance } \\
(\%)\end{array}$ & $\begin{array}{l}\text { Elevati } \\
\text { on }(\mathrm{m})\end{array}$ & $\begin{array}{l}\mathrm{Q} \\
\left(\mathrm{m}^{3} / \mathrm{s}\right)\end{array}$ & $\begin{array}{l}\text { Loss } \\
\text { (billion } \\
\text { IDR) }\end{array}$ \\
\hline 2 & 50 & 127.24 & 119.53 & 51.140 \\
5 & 20 & 127.57 & 178.77 & 68.880 \\
10 & 10 & 127.82 & 210.34 & 75.900 \\
25 & 4 & 127.9 & 244.28 & 84.960 \\
\hline
\end{tabular}

From Table 15, the loss-frequency curve can be developed into polynomial function. So that, lossfrequency curve can be estimated by choosing the upper and lower value for vertical axis is 300 and 0.2 respectively. The new relationship between estimated loss and probability of exceedance is then presented in Figure 12. The average annual damage is the average loss, which can be average to result from flow discharge with condition remaining unchanged.

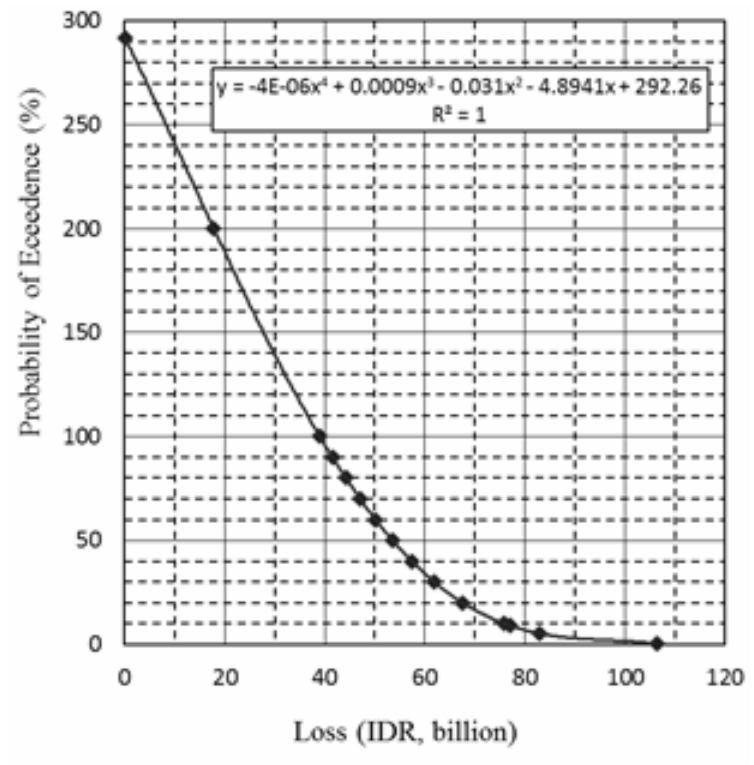

Figure 12. Loss-Frequency curve.

If the estimated loss, stage, flow, and frequency data are remaining the same in the future, the average annual damage value could be average to occur during another flood event. The area beneath loss-frequency curve is considered average annual damage. The integral of loss-frequency function with the upper and lower value are 0 and 106.34 respectively. The result of the integral computation on the Loss-frequency curve is IDR 88.75 billion. The use weighting of the loss value is commonly performed by rectangular area computation. Average annual damage can be approached by calculating the rectangular under the curve. One rectangular value means $10 \%$ of IDR 10 million loss. The curve can be adapted into rectangle approach. The rectangle area value is IDR 89.9 million with the upper value for vertical and horizontal axis are 290\% and IDR 62 billion respectively. The area under the curve may also be obtained from the integral of the equation from zero to approximately 107 IDR billion, and this may give average annual damage (AAD) at approximately IDR $88,750,000,000$.

\section{CONCLUSIONS AND SUGGESTIONS}

\subsection{Conclusions}

There are some conclusions, these include:

a) Based on the loss assessment model, there are several building types affected by flood, which are 
government offices, education buildings, hospital, place of recreation and residentials.

b) Based on the loss-frequency function, Average Annual Damage (AAD) is IDR 88,750,000,000,--

c) Loss-Frequency function can be used to estimate loss for any flood event in same condition on the future.

d) The flood prone area were located on the left of the river which has a lower elevation, the flood prone area are Tegalrejo, Bener, Kricak, and Bumijo villages.

\subsection{Recommendations}

The necessary recommendations for further analysis are as follows:

a) This research use spatial adjustment to update the building exposure. However, the field survey is more eligible to do to ensure based on the real condition.

b) Further research is needed, particularly on the subject of the effect on resin polymer concrete application as retrofitting and strengthening material on the joint with yielding reinforcement.

c) Further research is needed to produce equations that are especially used to make theoretical calculation on concrete cross section capacity.

\section{REFERENCES}

BNPB, 2012. Peraturan Kepala Badan Nasional Penanggulangan Bencana Nomor 02 Tahun 2012 Tentang Pedoman Umum Pengkajian Risiko Bencana, Jakarta: BNPB.

Hardika, M. R., 2017. Loss Modelling Assesment of Flood Damage, Yogyakarta: Master Thesis. Faculty of Engineering. Universitas Gadjah Mada.
Jonkman, S. N., Bockarjova, M., Kok, M. \& Bernardini, P., 2008. Integrated Hydrodinamic and Economic Modelling of Flood Damage in the Netherlands. ScienceDirect, pp. 77-90.

Maharani, R. D., 2016. Pemetaan Risiko Banjir Sungai Winongo Kota Yogyakarta, Yogyakarta: UGM.

Mas, A. D. P., 2015. Study on Flood Management Plan in Surabaya City. Journal of the Civil Engineering Forum, 1(2), pp. 51-56. doi: 10.22146/jcef.23891.

Pawestri, T. M., Sujono, J. \& Istiarto, 2016. Flood Hazard Mapping of Bogowonto River in Purworejo Regency, Central Java. Journal of the Civil Engineering Forum, 2(3), pp. 243-254. doi: 10.22146/jcef. 24348

U.S. Army, 1989. Expected Annual Flood Damage Computation, California: US Army Corps of Engineers Institute For Water Recources.

Waluyadi, H., 2007. Kajian penanganan banjir Kali Ciliwung DKI Jakarta ditinjau dari aspek HidroEkonomi : Studi kasus pada ruas Cawang-Pintu Air Manggarai, Yogyakarta: UGM. 
[this page intentionally left blank] 